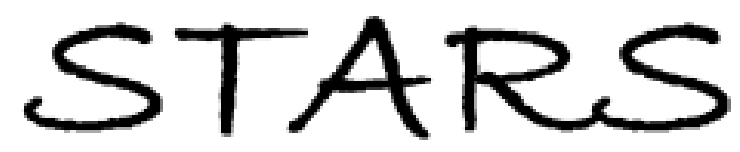

University of Central Florida

STARS

$1-1-2015$

\title{
Conducting polymer nanoparticles for targeted cancer therapy
}

\author{
Mona Doshi \\ University of Central Florida \\ Marissa Krienke \\ University of Central Florida \\ Saeid Khederzadeh \\ University of Central Florida \\ Henry Sanchez \\ University of Central Florida \\ Alicja Copik \\ University of Central Florida
}

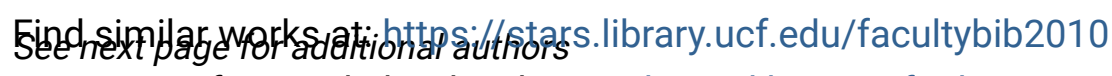

University of Central Florida Libraries http://library.ucf.edu

This Article is brought to you for free and open access by the Faculty Bibliography at STARS. It has been accepted for inclusion in Faculty Bibliography 2010 s by an authorized administrator of STARS. For more information, please contactSTARS@ucf.edu.

\section{Recommended Citation}

Doshi, Mona; Krienke, Marissa; Khederzadeh, Saeid; Sanchez, Henry; Copik, Alicja; Oyer, Jeremiah; and Gesquiere, Andre J., "Conducting polymer nanoparticles for targeted cancer therapy" (2015). Faculty Bibliography 2010s. 6511.

https://stars.library.ucf.edu/facultybib2010/6511

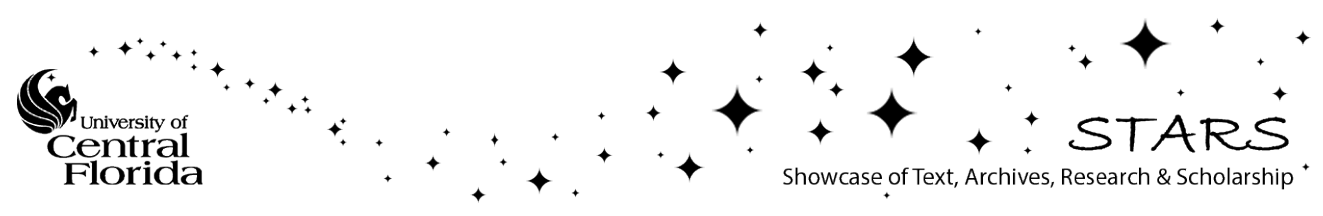




\section{Authors}

Mona Doshi, Marissa Krienke, Saeid Khederzadeh, Henry Sanchez, Alicja Copik, Jeremiah Oyer, and Andre J. Gesquiere 


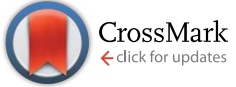

Cite this: RSC Adv., 2015, 5, 37943

\title{
Conducting polymer nanoparticles for targeted cancer therapy $\dagger$
}

\author{
Mona Doshi, ${ }^{\text {ab }}$ Marissa Krienke, ${ }^{\text {ac }}$ Saeid Khederzadeh, ${ }^{\text {ad }}$ Henry Sanchez, ${ }^{\text {ag }}$ \\ Alicja Copik, Jeremiah Oyer ${ }^{f}$ and Andre J. Gesquiere*abde
}

First and second generation photosensitizers used in photodynamic therapy (PDT) have shown promising results in clinical applications, aided by recent improvements in light absorption efficiency and quantum yield of singlet oxygen formation. However, these photosensitizers still have several drawbacks that prevent PDT from being an efficient therapy, including lack of selectivity to diseased tissue, observation of dark toxicity, and hydrophobicity of the sensitizer. Conducting polymers are promising candidates as next generation sensitizers for PDT due to their large extinction coefficients $\left(>10^{7} \mathrm{~L} \mathrm{~mol}^{-1} \mathrm{~cm}^{-1}\right)$, ability to undergo intersystem crossing to the triplet state at high rates, and triplet energies that are close to that of oxygen. Targeting of conducting polymer poly[2-methoxy-5-(2-ethylhexyl-oxy)- $p$ phenylenevinylene] (MEH-PPV) nanoparticles to folate receptors (FR) was achieved by development of blended nanoparticles containing amphiphilic polymer polystyrene graft ethylene oxide functionalized with carboxylic acid (PS-PEG-COOH) with chemically active moieties that can be functionalized with folic acid. The resulting organic nanoparticles are buffer stable and exhibit excellent biocompatibility in the dark. The functionalized nanoparticles (FNPs) were studied in OVCAR3 (ovarian cancer cell line, FR+), MIA PaCa2 (pancreatic cell line, FR-), and A549 (lung cancer cell line, marginally FR+). Complete selectivity of the FNPs towards FR+ cell lines was found, and is attributed to the hydrophobicity and large negative zeta potential of the nanoparticles. Quantification of PDT results by MTS assays and flow cytometry show that PDT treatment was fully selective to the FR overexpressing cell line (OVCAR3). No cell mortality was observed for the other cell lines studied here within experimental error.

Received 23rd March 2015 Accepted 13th April 2015

DOI: $10.1039 / c 5 r a 05125 h$

www.rsc.org/advances

\section{Introduction}

In the last two decades a steady decrease in cancer patient mortality has been achieved due to intensive research and improvements in treatments. ${ }^{1}$ However, for high mortality cancers such as pancreatic, liver, lung etc. no significant progress has been made. ${ }^{2}$ Therefore, a multitude of treatment

\footnotetext{
${ }^{a}$ NanoScience Technology Center, University of Central Florida, Orlando, FL 32826, USA. E-mail: andre@ucf.edu

${ }^{b}$ Department of Chemistry, University of Central Florida, Orlando, FL 32826, USA 'Department of Biology, University of Central Florida, Orlando, FL 32826, USA

${ }^{d}$ Department of Materials Science and Engineering, University of Central Florida, Orlando, FL 32826, USA

${ }^{e}$ The College of Optics and Photonics (CREOL), University of Central Florida, Orlando, FL 32826, USA

${ }^{f}$ Burnett School of Biomedical Sciences, College of Medicine, University of Central Florida, Orlando, FL 32827, USA

${ }^{8}$ Department of Materials Science and Engineering, Johns Hopkins University, Baltimore, MD 21218, USA

$\dagger$ Electronic supplementary information (ESI) available: Progression of centrifugal filtration by UV-vis and fluorescence spectroscopy, intrinsic cytotoxicity of FNPs supported by fluorescence imaging, 0 hours post-PDT cell viability and live-dead double staining for apoptosis and necrosis. See DOI: $10.1039 / \mathrm{c} 5 \mathrm{ra} 05125 \mathrm{~h}$
}

schemes are still being investigated to address existing needs in cancer therapeutics. Photodynamic therapy (PDT) is receiving increasing attention among researchers due to its ease of application and promising clinical results.,

In PDT a photosensitizer is administered to tissue and irradiated with visible light matching to the absorption spectrum of the photosensitizer., ${ }^{5,6}$ This brings the photosensitizer into its singlet excited state, which can then relax to the ground state through different pathways. Decay of the excited state by fluorescence makes it possible to use some sensitizers as a tool to locate diseased tissue, but only if the photosensitizer is targeted to that tissue. A fraction of the singlet excited state of the photosensitizer will intersystem cross to its long lived triplet excited state. The triplet state leads to the formation of Reactive Oxygen Species (ROS), highly reactive forms of oxygen, which are harmful to cells and can result in cell mortality. ${ }^{7-9}$ The mechanism by which the triplet state of the photosensitizer leads to formation of ROS involves two types of photooxidative pathways. In type I photooxidation charge transfer from the triplet state of the photosensitizer to molecular oxygen yields the reactive superoxide radical ion. Alternatively, this process can proceed with biomolecules and solvent molecules in the cells as the acceptors to form radicals. In type II photooxidation 
the triplet state of the photosensitizer transfers energy to the triplet ground state of oxygen to form singlet oxygen. ${ }^{5,7,10,11}$ The resulting elevated levels of ROS induce oxidative stress and cell death..$^{5,7,10,12,13}$

When a non-targeted photosensitizer is administered into the body, the patient has to be kept away from sunlight in order to avoid toxic side effects. Photosensitizers such as verteporfin, 5 -aminolevulinic acid, and photofrin cause skin diseases that manifest themselves by pigmentation, and phototoxic reactions which cause itching and burning sensation, swelling and erythema. ${ }^{\mathbf{1 4 , 1 5}}$ To address such side effects, the photosensitizer must be targeted towards the malignant tissue only. Nanoparticle technology has shown promise to improve the efficacy and selectiveness of sensitizer delivery towards malignant tissue, causing less side effects. During the last decade, monoclonal antibodies (MAbs) have been used to target cancers for diagnosis and treatment. ${ }^{\mathbf{1 6}}$ In photoimmunotherapy (PIT), MAbs were conjugated with photosensitizers such as haematoporphyrin derivative (HpD), chlorin e6 and phthalocyanines to achieve selective delivery of the photosensitizer in tumors. ${ }^{\mathbf{1 6}}$ However, the current issue with PIT is optimal control over the conjugate preparation without changing the biological properties of the monoclonal antibodies. ${ }^{16}$ Besides targeting cancers through specific antibody/antigen interactions, cancer cells can also be targeted by means of the well-documented overexpression of receptors such as folate receptors (FR), ${ }^{17,18}$ epidermal growth factor receptors (EGFR), ${ }^{\mathbf{1 9}}$ Her-2 receptors ${ }^{\mathbf{2 0 , 2 1}}$ and others depending on the type of cancer. Ligands specific towards these receptors such as folic acid (FA), antibodies Erbitux or Cetuximab, and affibody, respectively, can be used for enhanced selectivity of delivery. Research has been reported on targeting ovarian cancer with different ligands to make PDT more specific. Recently PDT using $\mathrm{Fe}_{3} \mathrm{O}_{4} / \mathrm{Au}$ NPs decorated with 5,10,15,20-tetrakis(4-hydroxyphenyl)-21 H,23H-porphine (tHPP) as a photosensitizer and affibody for Her-2 specificity to target SK-OV-3 ovarian cancer cells was studied. ${ }^{22}$ These NPs were evaluated in xenografted tumor and were found to be very effective in showing specificity and inhibition of tumor growth. EGFR targeted PDT using liposomes functionalized with Cetuximab as the targeting antibody and benzoporphyrine derivative (BPD) as photosensitizer yielded very promising results when applied to ovarian cancer cells. ${ }^{23}$ Research on the use of folic acid as a ligand for selective delivery of photosensitizer in different types of cancer tissues is also welldocumented and is still in progress. Polymeric micelles conjugated with folic acid to deliver meta-tetra (hydroxyphenyl) chlorin (mTHPC) in KB cells in vitro and corresponding xenografts were studied by Syu et al. ${ }^{24} \mathrm{CdTe}$ quantum dots acting as a photosensitizer and conjugated with folic acid showed specificity to folate receptor (FR) overexpressing KB cells. ${ }^{25}$ Similarly, zinc tetraaminophthalocyanine $(\mathrm{ZnaPc})$ conjugated with folic acid showed selective delivery of the photosensitizer to FR positive (FR+) KB cells. ${ }^{26}$ Graphene oxide nanoparticles loaded with photosensitizer chlorin e6 (Ce6) and conjugated with folic acid recently showed promise when studied in vitro with MGC803 cells. ${ }^{27}$
Photosensitizers that are currently applied in PDT have moderate extinction coefficients and have high singlet oxygen quantum yield, which has provided promising result for PDT treatment in clinical settings. ${ }^{28,29}$ Though a lot of work has been completed to improve the properties of photosensitizers to make PDT an effective treatment for cancer with only minor to no side effects, there still remain a few problems that need to be addressed. These include (1) lack of specificity, which leads to side effects such as damage to healthy tissue and prolonged photosensitivity of the patient, (2) hydrophobicity of sensitizer molecules that leads to aggregation and thus reduced bioavailability and efficacy of the photosensitizer, and (3) dark toxicity of the photosensitizers, which could limit applicability of the photosensitizer, especially if non-targeted sensitizers.

Photosensitizer doped conjugated polymer nanoparticles have recently received attention as next generation photosensitizers in PDT. Grimland et al. have recently studied conducting polymer nanoparticles acting as nanocarriers encapsulating the photosensitizer tetraphenylporphyrine (TPP). ${ }^{30}$ The investigators showed formation of singlet oxygen by UV-vis spectroscopy after photoactivating the nanoparticles by one and two photon excitation. As a proof-of-concept DNA damage was shown in presence of these nanoparticles. Shen et al. also proved the generation of singlet oxygen by tetraphenylporphyrine (TPP) doped in conjugated polymer nanoparticles by photoluminescence of singlet oxygen by fluorescence spectroscopy. ${ }^{31}$ Similarly, Zhang et al. used meta-tetra-(hydroxyphenyl)chlorin ( $m$-THPC) as the photosensitizer in conjugated polymer nanoparticles to form ROS. ${ }^{32}$

In this article, blended poly[2-methoxy-5-(2-ethylhexyl-oxy)- $p$ phenylenevinylene] (MEH-PPV)/polystyrene graft ethylene oxide functionalized with carboxylic acid (PS-PEG-COOH) nanoparticles conjugated with folic acid (FNPs) were studied in vitro for use in PDT as next generation photosensitizers with targeted delivery. The nanoparticles were fabricated by self-aggregation of the polymer; the only chemistry that was applied was to conjugate folic acid to the nanoparticles. The FNPs are not cytotoxic in dark, and are highly effective at producing ROS under illumination due to the large extinction coefficient of MEH-PPV $\left(>10^{7} \mathrm{~L} \mathrm{~mol}^{-1} \mathrm{~cm}^{-1}\right)$. The combination of the hydrophobicity of MEH-PPV, large negative zeta potential of the nanoparticles, and receptor mediated uptake resulted in complete selectivity of FNP uptake by cancer cell lines that overexpress folate receptors (FR). Among the cancer cell lines studied MIA PaCa2 (pancreatic cancer cell line, no FR overexpression) does not show detectable uptake of FNPs, A549 (lung cancer cell line, minor FR overexpression) shows minor FNP uptake, and OVCAR3 (ovarian cancer cell line, major FR overexpression) shows abundant FNP uptake. PDT results quantified by MTS assay and confirmed by flow cytometry scale with the observed FNP uptake as expected. These results indicate the promising nature of this photosensitizer system due to its lack of dark toxicity, inclusion of PEG for enhanced circulation times, high rate of ROS generation, high cell mortality for the cancer cell line that abundantly overexpresses the targeted receptor (OVCAR3), while no cell mortality is observed for nontargeted (TE 71 normal control and MIA PaCa-2) or marginally 
receptor overexpressing cell lines (A549), and bright fluorescence that together with the high degree of selectivity can be used to localize the targeted tissue.

\section{Experimental section}

\section{Materials}

Poly[2-methoxy-5-(2-ethylhexyloxy)-1,4-phenylenevinylene] (MEHPPV) with molecular weight $150000-250000 \mathrm{~g} \mathrm{~mol}^{-1}$ (average Mn, PDI 2.2) was purchased from Sigma-Aldrich. For molarity calculations $\mathrm{Mn}$ of $200000 \mathrm{~g} \mathrm{~mol}^{-1}\left(\mathrm{Mw}=4.4 \times 10^{5} \mathrm{~g} \mathrm{~mol}^{-1}\right)$ was used. The polymer was purified to remove low molecular weight polymer chains. Comb-like polymer Polystyrene Graft Ethylene Oxide functionalized with carboxylic acid (PS-PEG$\mathrm{COOH}$ ) with molecular weight of $36500 \mathrm{~g} \mathrm{~mol}^{-1}$ (average Mn, PDI 1.3, Mw $=47450 \mathrm{~g} \mathrm{~mol}^{-1}$ ) was purchased from Polymer Source Inc and used as is. THF (tetrahydrofuran, Drisolv) was purchased from EMD. $\mathrm{N}$-Hydroxysuccinimide (NHS), $\mathrm{N}$-(3-dimethylaminopropyl)- $N$ '-ethylcarbodiimide hydrochloride (EDC) and folic acid were purchased from Sigma-Aldrich.

\section{Purification of MEH-PPV}

To purify MEH-PPV $6 \mathrm{ml}$ of HPLC grade acetone was added to 3 $\mathrm{mg}$ MEH-PPV in a vial. The vial was heated gently at a low temperature on a hot plate. The supernatant was observed to turn yellow and was removed using a glass pipette without removing the MEH-PPV at the bottom of the vial. A small amount of chloroform (approximately $3 \mathrm{ml}$ ) was added to this vial to dissolve MEH-PPV. To this orange solution acetone was added in a $1: 5$ ratio of chloroform to acetone. This suspension was transferred to a centrifuge tube and centrifuged for 10 minutes at $4000 \mathrm{rpm}$. The high molecular weight MEH-PPV settled at the bottom while the low molecular weight $\mathrm{MEH}$ PPV remained in the supernatant. The supernatant was removed and the procedure was repeated until the supernatant showed a light pink color (around four repetitions). The purified MEH-PPV was dried overnight before use.

\section{Fabrication of MPNPs}

$1 \mathrm{mg}$ purified MEH-PPV was dissolved in $3 \mathrm{ml}$ THF to obtain a $0.33 \mathrm{mg} \mathrm{ml}^{-1}$ stock solution of MEH-PPV and $1 \mathrm{mg}$ PS-PEG$\mathrm{COOH}$ was dissolved in $50 \mathrm{ml}$ THF to obtain a $0.02 \mathrm{mg} \mathrm{ml}^{-1}$ solution of PS-PEG-COOH. An approximately $2: 1$ molar ratio solution of MEH-PPV and PS-PEG-COOH was prepared by adding $1 \mathrm{ml}$ of MEH-PPV stock solution to $1 \mathrm{ml}$ PS-PEG-COOH stock solution. This mixture was then diluted further with approximately $3 \mathrm{ml}$ THF to achieve a $10^{-6} \mathrm{M}$ concentration of MEH-PPV and PS-PEG-COOH. $1 \mathrm{ml}$ of this diluted solution was quickly injected into $4 \mathrm{ml}$ of DI water under vigorous stirring. Stirring was stopped immediately after injection of the solution into water. The resulting suspension of MPNPs (MEH-PPV-PS-PEG-COOH blended nanoparticles) in water was used for preparation of folic acid functionalized nanoparticles (FNPs).

\section{Functionalization of MPNPs}

To chemically link folic acid to the MPNPs, the carboxylic acid groups of PS-PEG-COOH present in these MPNPs were first activated with NHS and EDC. NHS was added in excess to the MPNP suspension. After 15 minutes of stirring excess EDC was added to this solution. The solution of MPNPs, NHS and EDC was stirred again for 15 minutes. As folic acid is not soluble in water, it was dissolved in $1 \mathrm{M}$ sodium hydroxide first and then was added to the solution of MPNPs reacted with NHS/EDC in a 1 : 1 molar ratio of PS-PEG-COOH : folic acid. This solution was stirred for 2 hours at room temperature. The solution obtained is unfiltered functionalized nanoparticles (unfiltered FNPs).

\section{Centrifugal filtration of FNPs}

$15 \mathrm{ml}$ of FNPs were filtered by centrifugal filtration to remove the unreacted folic acid, NHS and EDC from the solution. Amicon Ultra-15 centrifugal filter devices with molecular weight cutoff $10000 \mathrm{kDa}$ was used for filtration. The solution was spun at $4000 \times g$ in a swinging bucket rotor for 60 minutes. To remove the unreacted NHS, EDC and folic acid from the FNPs solution, 6 to 7 filtrations were needed. After each filtration cycle approximately $3 \mathrm{ml}$ of filtrate were removed and the volume of the FNPs solution was adjusted back to $15 \mathrm{ml}$ by adding DI water, effectively replacing the unreacted folic acid, NHS and EDC from the solution with DI water. Progress was monitored by UV-vis and fluorescence spectroscopy completed for each filtrate (Fig. S3†).

\section{UV-visible spectroscopy}

Absorption spectroscopy on the NPs suspension in water was done in a $1 \mathrm{~cm}$ path length quartz cuvette with Agilent 8453 spectrophotometer using UV-visible chemstation software.

\section{Fluorescence spectroscopy}

Fluorescence spectroscopy on the NPs suspension in water was performed in a $1 \mathrm{~cm}$ path length quartz cuvette with Nanolog ${ }^{\mathrm{TM}}$ HoribaJobin Yvon fluorimeter.

\section{Cell culture}

TE 71 (mouse thymic epithelial cell line), MIA PaCa-2 (human pancreatic cancer cell line), A549 (human lung cancer cell line) and OVCAR3 (human ovarian tumor cell line) were grown in DMEM media supplemented with $10 \%$ FBS in humidified atmosphere of $95 \%$ air $/ 5 \% \mathrm{CO}_{2}$ at $37{ }^{\circ} \mathrm{C}$.

\section{Incubation with NPs for fluorescence imaging}

TE 71, MIA PaCa-2, A549 and OVCAR3 cell lines were grown in $35 \mathrm{~mm}$ Petri dishes for 24 hours. Then the media was removed and after washing with PBS the cells were incubated with $2 \times$ $10^{-4} \mathrm{mg} \mathrm{ml}^{-1}$ NPs in DMEM media supplemented with $10 \%$ FBS. After 24 hours the NPs solution was removed and cells were washed with PBS. Then the cells were fixed with $4 \%$ paraformaldehyde and stained with DAPI and suspended in PBS to image. 


\section{Imaging for uptake of NPs}

The fixed cells were imaged by epiluminescence microscope (Olympus IX 51) by using $60 \times$ objective, mercury lamp for fluorescence and FITC filters to detect the fluorescence from NPs and DAPI filters to detect fluorescence from nucleus stained with DAPI. The images were acquired by Andor Zyla sCMOS (DG-152V-C1E-FI) camera The NP images and DAPI images were overlaid using Image (NIH) software.

\section{Flow cytometry for uptake quantification}

$1 \times 10^{6}$ cells per ml concentration solutions of TE 71, MIA PaCa2, A549 and OVCAR3 cell lines were incubated with $2 \times 10^{-4} \mathrm{mg}$ $\mathrm{ml}^{-1}$ FNPs for 24 hours. Then the cells were harvested, washed and fixed with $4 \%$ paraformaldehyde and flow cytometry was performed on these samples by BD Canto II flow cytometer. The data was analyzed by using FlowJo software.

\section{Intrinsic cytotoxicity of FNPs}

The cells were grown in 96 well plates and were incubated with the different doses of FNPs $\left(0.4 \times 10^{-4} \mathrm{mg} \mathrm{ml}^{-1}, 2 \times 10^{-4} \mathrm{mg}\right.$ $\mathrm{ml}^{-1}$ and $\left.3.6 \times 10^{-4} \mathrm{mg} \mathrm{ml}^{-1}\right)$ along with one control dose $(0$ $\mathrm{mg} \mathrm{ml}^{-1}$ ) cells were incubated with CPNPs for up to 24 hours. Cell viability was determined $0,24,48,72$ and 96 hours after addition of CPNPs by MTS assay. For the 0 and 24 hour time point, MTS was added immediately after adding FNPs and 24 hours after addition of CPNPs, respectively. For the 48, 72 and 96 hours readings, the FNPs solution was removed after 24 hours and replaced with regular media (DMEM media supplemented with $10 \%$ FBS). MTS was then added at the corresponding time points. MTS was allowed to incubate for 4 hours to allow formazan to form. Then the readings were taken at 490 $\mathrm{nm}$ on Biotek ELx800 absorbance microplate reader.

\section{Detection of ROS}

The TE 71, MIA PaCa-2, A549 and OVCAR3 cells were incubated with $2 \times 10^{-4} \mathrm{mg} \mathrm{ml}^{-1}$ of FNPs. After 24 hours the media was replaced with HBSS (Hank's Balanced Salt Solution) and $180 \mathrm{~J}$ $\mathrm{cm}^{-2}$ light dose was given by using Newport 67005 Oriel Instruments and a UV filter (FSQ-GG400) to block the UV light. The CellROX green reagent purchased from Invitrogen was added to the media after 2 hours of post-PDT incubation. After 30 minutes the reagent was washed and the cells were fixed with $4 \%$ paraformaldehyde and stained with DAPI. The cells were kept in PBS for imaging. 3 negative controls (1) no FNPs and no light dose, (2) only light dose of $180 \mathrm{~J} \mathrm{~cm}^{-2}$, and (3) only FNPs dose of $2 \times 10^{-4} \mathrm{mg} \mathrm{ml}^{-1}$, and one positive control with $100 \mu \mathrm{M}$ $\mathrm{H}_{2} \mathrm{O}_{2}$ were also performed.

\section{Imaging for ROS detection}

The fixed cells were imaged by epiluminescence microscope (Olympus IX 51) by using $60 \times$ objective and mercury lamp for fluorescence. The images were acquired by Andor Zyla sCMOS (DG-152V-C1E-FI) camera. Excitation filter 491/10 and emission filter 525/50 were used to detect the fluorescence from CellRox green reagent. DAPI filters were used to detect fluorescence from DAPI stained to nucleus. FNP fluorescence was collected by using excitation filter $488 / 10$ and emission filter 600LP. The images were overlaid using ImageJ (NIH) software.

\section{Viability after PDT treatment}

Three light doses $\left(60 \mathrm{~J} \mathrm{~cm}^{-2}, 120 \mathrm{~J} \mathrm{~cm}^{-2}\right.$ and $\left.180 \mathrm{~J} \mathrm{~cm}^{-2}\right)$ and three FNPs doses $\left(0.4 \times 10^{-4} \mathrm{mg} \mathrm{ml}^{-1}, 2 \times 10^{-4} \mathrm{mg} \mathrm{ml}^{-1}\right.$ and $\left.3.6 \times 10^{-4} \mathrm{mg} \mathrm{ml}^{-1}\right)$ along with one control dose $\left(0 \mathrm{mg} \mathrm{ml}^{-1}\right)$ were used for PDT. For each light dose two post-PDT incubation periods ( 0 hours and 4 hours) were given. Thus cell lines were grown in six 96-well plates (3 light doses $\times 2$ post-PDT incubation periods). The cell lines were grown for 24 hours. Then the cells were incubated with different doses of FNPs. After 24 hours the media was replaced with HBSS and the 96 well plates with the cells were exposed to visible light by using a solar simulator (Newport 67005 Oriel Instruments) and a UV filter (FSQ-GG400) to block the UV light. Then MTS was added to the 96 well plates immediately after PDT ( 0 hours) and 4 hours postPDT incubation. MTS was allowed to incubate for 4 hours to allow formazan to form. Then the readings were taken at 490 $\mathrm{nm}$ on Biotek ELx800 absorbance microplate reader. The experiment was performed 3 times $(n=3)$.

\section{Flow cytometry for apoptosis and necrosis}

$1 \times 10^{6}$ cells per $\mathrm{ml}$ concentration solutions of TE 71, MIA PaCa2, A549 and OVCAR3 cell lines were incubated with $2 \times 10^{-4} \mathrm{mg}$ $\mathrm{ml}^{-1}$ FNPs for 24 hours. Then the cells were irradiated with 180 $\mathrm{J} \mathrm{cm}^{-2}$ light dose and incubated for another 4 hours. Then the cells were harvested and stained with annexin V-FITC and PI (propidium iodide). The samples were kept on ice. Flow cytometry was performed on these samples by BD Canto II flow cytometer. The data was analysed by using FlowJo software.

\section{Results and discussion}

\section{Fabrication, functionalization and characterization of NPs}

The nanoparticles (NPs) to be functionalized were fabricated by the reprecipitation method, following a modified procedure from the one published by Wu et al. ${ }^{33}$ In short, a solution of $2: 1$ molar ratio of fluorescent hydrophobic polymer MEH-PPV and non-fluorescent comb-like amphiphilic polymer PS-PEG-COOH in THF was quickly injected into DI water under vigorous stirring. Due to their hydrophobicity, the MEH-PPV polymer chains and the polystyrene backbone of PS-PEG-COOH polymer aggregate to form MPNP suspension in water. The hydrophilic PEG and $\mathrm{COOH}$ parts of the non-fluorescent polymer extend towards water making the carboxylic acid groups available on the surface of the MPNPs for further modifications. The carboxylic acid groups were then allowed for attachment of ligands to the MPNPs. Scheme 1 shows the complete process of MPNP fabrication and functionalization by conjugation of folic acid to the $\mathrm{COOH}$ groups.

After MPNP fabrication NHS and EDC was added to the MPNPs suspension (Scheme 1 step 2 and 3) in order to activate the hydroxyl groups of $\mathrm{COOH}$ on the MPNPs surface by forming 


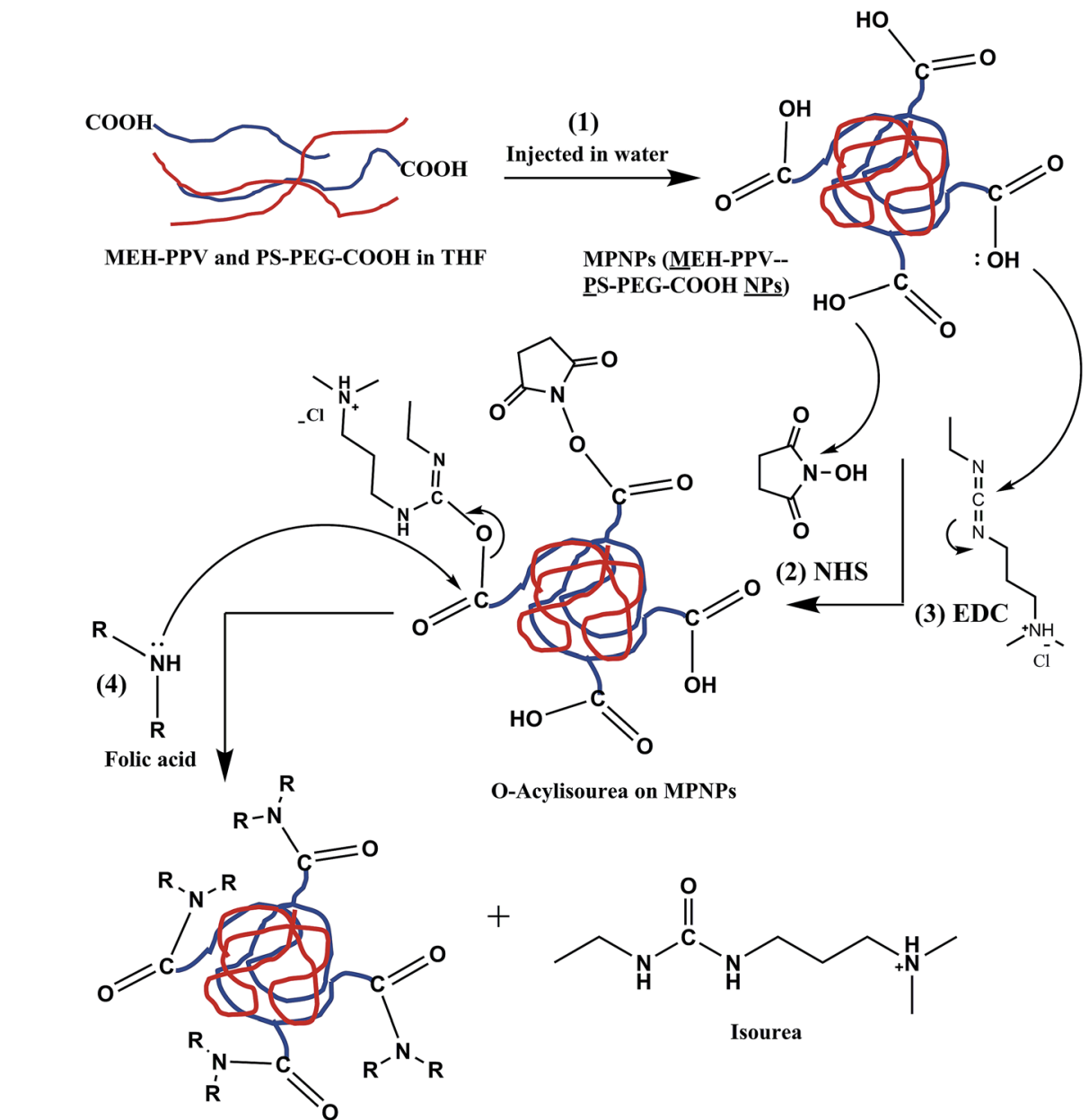

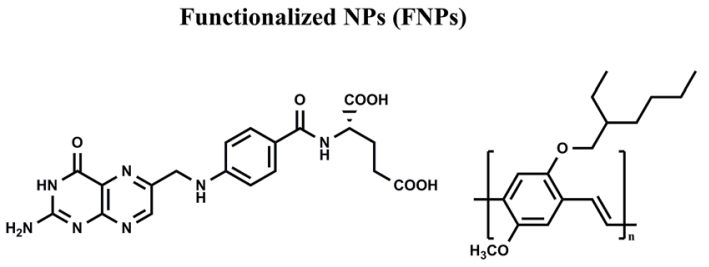

(A) Folic Acid (FA)

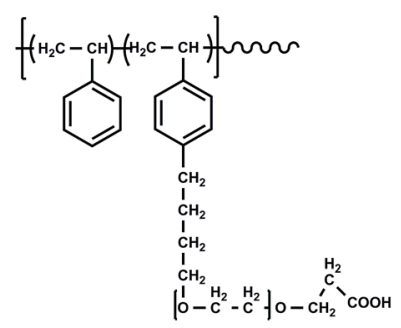

(C) PS-PEG-COOH

Scheme 1 Functionalization of MPNPs with folic acid by EDC reaction. (1) Formation of MPNPs from mixed solution of MEH-PPV and PS-PEG$\mathrm{COOH}$ in THF, (2) and (3) addition of NHS and EDC respectively to activate the carboxyl OH groups, forming the $O$-acylisourea group on MPNPs, (4) conjugation of folic acid to MPNPs through the formation of an amide bond.

the $O$-acylisourea product, which is a better leaving group. Upon addition of $1: 1$ molar ratio of folic acid to PS-PEG-COOH in the $O$-acylisourea product, folic acid conjugates to the MPNPs by formation of an amide bond between the amine of folic acid and the carbonyl group of MPNPs while replacing the isourea group (Scheme 1 step 4). Unreacted folic acid was removed by centrifugal filtration. The filtered solution is a suspension of the functionalized NPs (FNPs) in water.

Formation of an amide bond between the carbonyl of MPNPs and amine of folic acid was confirmed by FTIR. Fig. 1A shows the FTIR spectra of MPNPs, FNPs and MEH-PPV NPs. Fig. 1B has the same spectra enlarged from 1000 to $2000 \mathrm{~cm}^{-1}$. There are no major differences between the spectra of MPNPs and MEH-PPV NPs suggesting that there is no chemical bond formation when PS-PEG-COOH and MEH-PPV polymers were mixed with each other to fabricate MPNPs. Three particular amide bands in the FTIR spectrum of FNPs (blue line), (1) amide $\mathrm{I}-\mathrm{C}=\mathrm{O}$ stretch at $1620 \mathrm{~cm}^{-1},(2)$ amide II $-\mathrm{NH}$ bend at 1580 $\mathrm{cm}^{-1}$, and (3) amide III $-1312 \mathrm{~cm}^{-1}$,confirm that the expected amide bond was formed. There is one primary amine (pterine ring) and one secondary amine ( $p$-aminobenzoate moiety) in folic acid (Scheme 1) which can form an amide bond with the carbonyl on MPNPs. ${ }^{34,35}$ Chen et al. have recently shown that even though the pterine moiety in folic acid is essential for the 


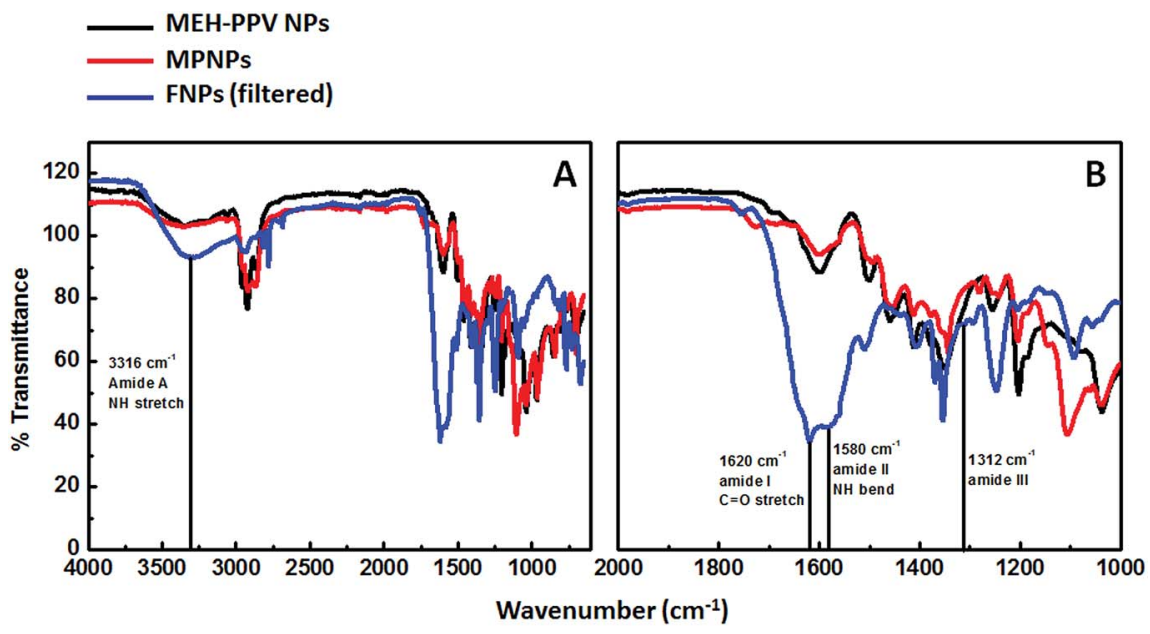

Fig. 1 (A) FTIR spectra of FNPs (blue line) compared with MEH-PPV NPs (black line) and MPNPs (red line). The three particular amide bands at $1620 \mathrm{~cm}^{-1}$ - (amide I) for $\mathrm{C}=\mathrm{O}$ stretch, $1580 \mathrm{~cm}^{-1}$ (amide II) for NH bend and $1312 \mathrm{~cm}^{-1}$ (amide III) in FNPs spectrum confirm the formation of amide bond between amine of folic acid and carbonyl on MPNPs.

binding affinity to folate receptors, extensive interactions between the glutamate group in folic acid and side chains of the proteins lining the groove of folate receptors could be observed, specifically through six hydrogen bonds and some backbone interactions. ${ }^{36}$ Thus even if the primary amine in the pterine ring is compromised during the conjugation of folic acid to MPNPs, the uptake efficiency should not be significantly affected. Also, the conjugation might have occurred through the secondary amine of $p$-aminobenzoate moiety of folic acid. The uptake measurements in OVCAR3 cell line (vide infra) show that the uptake efficiency was indeed not compromised.

The zeta potential measurements revealed that the MPNPs have a negative zeta potential of $-50.8 \pm 6.21 \mathrm{mV}$ on them. The high negative charge on MPNPs might be due to the $\mathrm{COOH}$ groups protruding out on the surface of MPNPs. This also confirms the assumption that the hydrophilic parts of PS-PEG$\mathrm{COOH}$ extends out on the surface of MPNPs. The FNPs also have a zeta potential of $-48.9 \pm 8.36 \mathrm{mV}$ due to the few conjugated folic acid molecules and the remaining unreacted $\mathrm{COOH}$ groups on the surface of FNPs.

The optical properties of the MPNPs and FNPs were measured by UV-vis and fluorescence spectroscopy (Fig. 2A and B). The UV-vis spectra (Fig. 2A) of the MPNPs (black line) and FNPs before centrifugal filtration (red line) have $\lambda_{\max } 497 \mathrm{~nm}$ while the $\lambda_{\max }$ of FNPs after centrifugal filtration (blue line) is blue shifted by $5 \mathrm{~nm}$ and has $\lambda_{\max }$ at $492 \mathrm{~nm}$. The blue shift in the $\lambda_{\max }$ might be attributed to compacting of the FNPs and collapse of polymer chains within the FNPs when residual THF is extracted from the FNPs during the centrifugal filtration. The collapse of the polymer chains inside the FNPs leads to severe kinking and bending of conjugated backbone of polymers which results in reduced conjugation length leading to the blue shift in absorption spectra. ${ }^{37-40}$

The fluorescence spectra (Fig. 2B) of MEH-PPV have $\lambda_{\max }$ at $589 \mathrm{~nm}$, even though the fluorescent intensity of the FNPs after filtration is drastically reduced to $40 \%$. This effect again can be attributed to the removal of THF during centrifugal filtration. When THF is removed the FNPs may become compacted, which can result in lowered quantum efficiency of fluorescence due to self-quenching. ${ }^{41}$

The presence of folic acid in FNPs suspension was confirmed by acquiring emission of folic acid by exciting the FNPs at 300 nm (Fig. 2C). The fluorescence spectrum of folic acid in FNPs before filtration (red line) has $\lambda_{\max }$ at $402 \mathrm{~nm}$. After filtration the fluorescence intensity of folic acid in FNPs (blue line) decreases as the unreacted folic acid is removed from the solution, although the $\lambda_{\max }$ remains unaltered.

It has previously been reported that MEH-PPV NPs fabricated by the reprecipitation method have a diameter of about $35 \mathrm{~nm}$ in diameter. ${ }^{39}$ When MPNPs were fabricated from a mixture of $2: 1$ molar ratio of PS-PEG-COOH and MEH-PPV by the reprecipitation method, the size was measured to be $45.12 \pm 4.60 \mathrm{~nm}$ by DLS (Table 1). After folic acid conjugation the size of FNPs before filtration decreased slightly to $39.81 \pm 5.12 \mathrm{~nm}$ as compared to MPNPs. After filtration the size of FNPs increased to $68.80 \pm 7.30 \mathrm{~nm}$, which is attributed to aggregation of a few FNPs (see Fig. S1 for AFM images and S2 for DLS data in the ESI $\dagger$ ).

\section{Uptake of NPs}

As the zeta potential on the surfaces of FNPs is $-48.9 \pm 8.36 \mathrm{mV}$, it was expected that due to such a high negative charge there would be no or limited non-specific uptake of FNPs in any of the cell lines. ${ }^{42-45}$ Due to the presence of folic acid on FNPs, it was speculated that regardless of the high negative charge on the surfaces of FNPs, a receptor mediated uptake of FNPs would occur in cell lines which overexpress folate receptors (FRs) on their cell membranes. Fig. 3 shows the qualitative uptake of FNPs in OVCAR3, A549, MIA PaCa-2, and TE-71 cell lines by epiluminescence imaging. As it is well known that over $90 \%$ of ovarian cancer cells overexpress FRs, ${ }^{17,46-49}$ and the expression of FRs on ovarian carcinoma is very homogenous, ${ }^{50}$ the OVACR3 

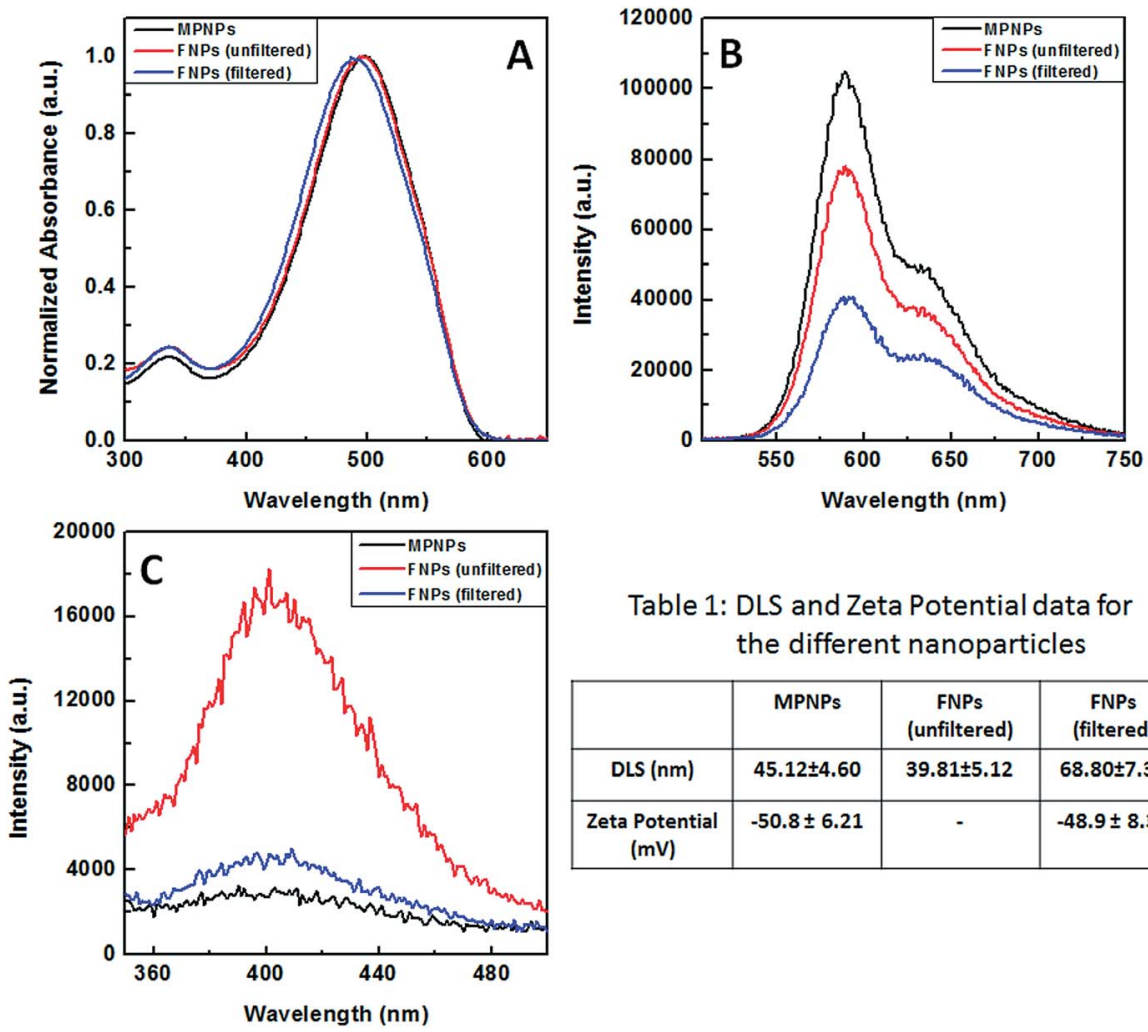

Table 1: DLS and Zeta Potential data for the different nanoparticles

\begin{tabular}{|c|c|c|c|}
\hline & MPNPs & $\begin{array}{c}\text { FNPs } \\
\text { (unfiltered) }\end{array}$ & $\begin{array}{c}\text { FNPs } \\
\text { (filtered) }\end{array}$ \\
\hline DLS (nm) & $45.12 \pm 4.60$ & $39.81 \pm 5.12$ & $68.80 \pm 7.30$ \\
\hline $\begin{array}{c}\text { Zeta Potential } \\
(\mathrm{mV})\end{array}$ & $-50.8 \pm 6.21$ & - & $-48.9 \pm 8.36$ \\
\hline
\end{tabular}

Fig. 2 (A) UV-vis spectra of NPs suspended in water. The absorption maxima for MPNPs and FNPs before filtration are $497 \mathrm{~nm}$. After filtration the absorption maximum shifts to $492 \mathrm{~nm}$. NP fluorescence spectra were collected for excitation at (B) MEH-PPV absorption and (C) folic acid absorption. The $\lambda_{\max }$ of emission spectra in (B) for the three different NPs is $589 \mathrm{~nm}$, although the intensity of fluorescence is reduced to approximately $40 \%$ after filtration. In (C) the fluorescence of folic acid has $\lambda_{\max }$ at $402 \mathrm{~nm}$. After filtration the observed intensity of folic acid fluorescence is reduced due to removal of unreacted folic acid from FNP solution (also see Fig. S3†). Table 1 shows the size of NPs determined by DLS and the zeta potential on their surfaces. For the unfiltered FNPs zeta potential data could not be obtained due to the free folic acid and excess NHS and EDC present in solution.
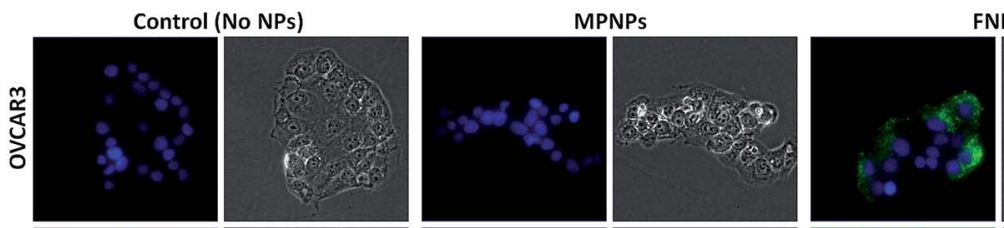

FNPs
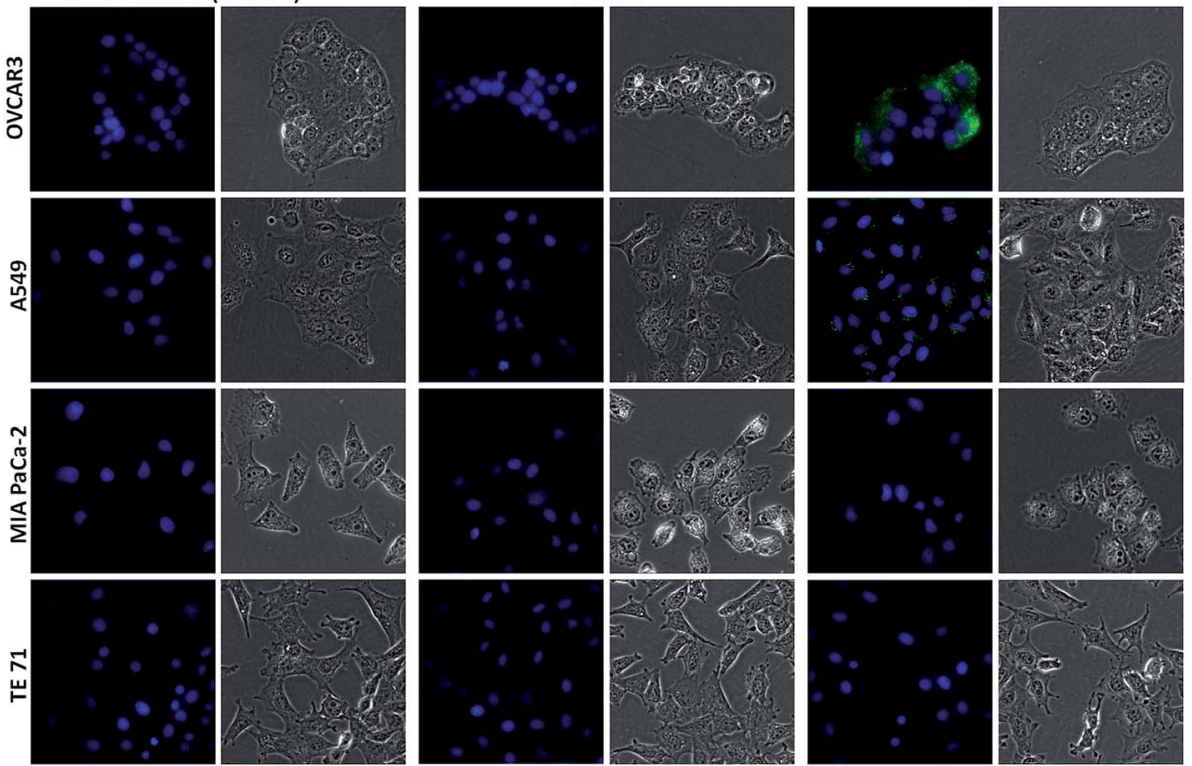

Fig. 3 Uptake of FNPs in OVCAR3, A549, MIA PaCa-2 and TE 71 cell lines. The fluorescence images represent FNPs fluorescence (green) and DAPI fluorescence (blue). The corresponding phase contrast images are also shown. The left column shows the control images, the middle column shows images for cells treated with MPNPs and the right column shows images for cells treated with FNPs. 
cell line was selected as the FR positive (FR+) cell line to observe the specific or receptor mediated uptake of FNPs. The expression of FRs in A549 is marginal at best, if not absent, ${ }^{\mathbf{4 9}, 51-59}$ while in the MIA PaCa-2 cell line there are receptors other than FRs (FR-), like thrombin receptors ${ }^{60}$ or EGFR. ${ }^{61}$ Thus these two cancer cell lines were chosen as negative controls. The TE 71 cell line was chosen as a control normal cell line which has marginal to no FRs. It was observed that when all four cell lines were incubated with $2 \times 10^{-4} \mathrm{mg} \mathrm{ml}^{-1}$ dose of FNPs, the uptake of FNPs was highest in OVCAR3 due to high amount of FRs expressed in this cell line, while in A549 the uptake of FNPs was limited as it has few to no FRs. MIA PaCa- 2 and TE 71 have no detectable fluorescence suggesting no uptake of FNPs in these cell lines. To rule out the possibility of non-specific uptake in OVCAR3 or in A549 all the cell lines were incubated with an equal dose of MPNPs, which are not conjugated with folic acid (Fig. 3). It was observed that there was no detectable fluorescence from MPNPs in any of the four cell lines suggesting that there was no non-specific uptake of MPNPs. This observation infers that for receptor mediated uptake of NPs, the presence of FRs on cell membranes and the presence of folic acid on the NPs surface was necessary.

To determine the selectivity of FNP uptake, flow cytometry was performed on the cell lines after incubating them with a 2 $\times 10^{-4} \mathrm{mg} \mathrm{ml}^{-1}$ dose of FNPs. Fig. 4 shows the flow cytometry results. TE 71, MIA PaCa-2 and A549 data show that $0 \%$ cell population has uptaken FNPs, while for the OVCAR3 cell line $85 \%$ of the cell population has uptaken FNPs. Although epiluminescence imaging shows small amounts of FNPs in A549 cells, flow cytometry was unable to detect this fluorescence. In addition, PDT did not induce cell mortality in this case (vide infra). The selectivity of the FNPs towards OVCAR3, which is the folate overexpressing cell line, is easily explained by the conjugation of the FNPs with folic acid, while the limited uptake by A549 is attributed to the few FRs available on the cell surface. In addition, the lack of uptake by the other cell lines can be attributed to the hydrophobicity and the high negative zeta potential of the FNPs, which makes non-receptor mediated uptake unlikely.

\section{Intrinsic cytotoxicity of FNPs}

The cytotoxicity of the FNPs in dark (intrinsic cytotoxicity) was studied by quantifying the proliferation of the cell lines in presence of FNPs by MTS cell viability assay. Data are shown in Fig. 5 for TE 71, MIA PaCa-2, A549 and OVCAR3 cell lines. For each cell line the \% cell viability at each FNPs dose is normalized to the control dose. Cell viability was observed to be about $100 \%$ at each dose of FNPs up to 96 hours. No cell mortality is observed for the TE 71 and MIA PaCa-2 cell lines, which at first glance appears trivial due to the lack of FNP uptake. However, the presence of the FNPs in the cell culture media also did not result in cell mortality. For A549 limited FNP uptake was observed, while for OVCAR3 abundant FNP uptake occurred (Fig. 3). Again, in neither case cell mortality is observed. The FNPs clearly do not affect the normal functioning of cells, and cells in the presence of FNPs proliferate normally (Fig. S4 $\dagger$ ).

\section{Generation of oxidative stress in cells after PDT}

It is well known that when conducting polymers absorb light, it can intersystem cross and form triplet excited states. In case of MEH-PPV the probability of intersystem crossing and forming triplet excited states is $1.25 \% .{ }^{62}$ These triplet states can dissipate to the ground state by energy transfer to triplet ground state of
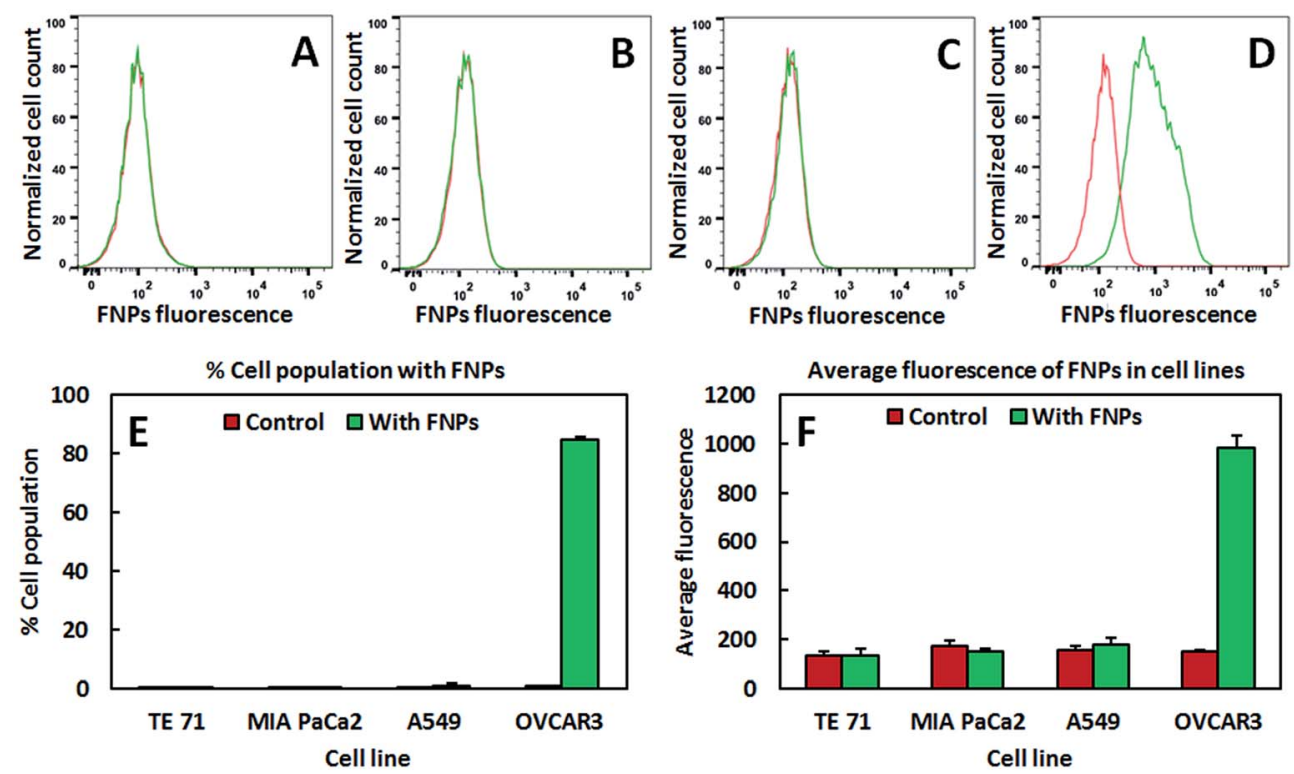

Fig. 4 Uptake of FNPs was quantified by flow cytometry for the (A) TE 71, (B) MIA PaCa-2, (C) A549, and (D) OVCAR3 cell lines. Red line normalized percent population of control cells, Green line - normalized percent population of cells incubated with FNPs. (E) Bar graph indicating the percentage of the cell population that has uptaken FNPs compared to the control (no FNPs). (F) Bar graph indicating the average fluorescence intensity of FNPs detected for the different cell lines. 

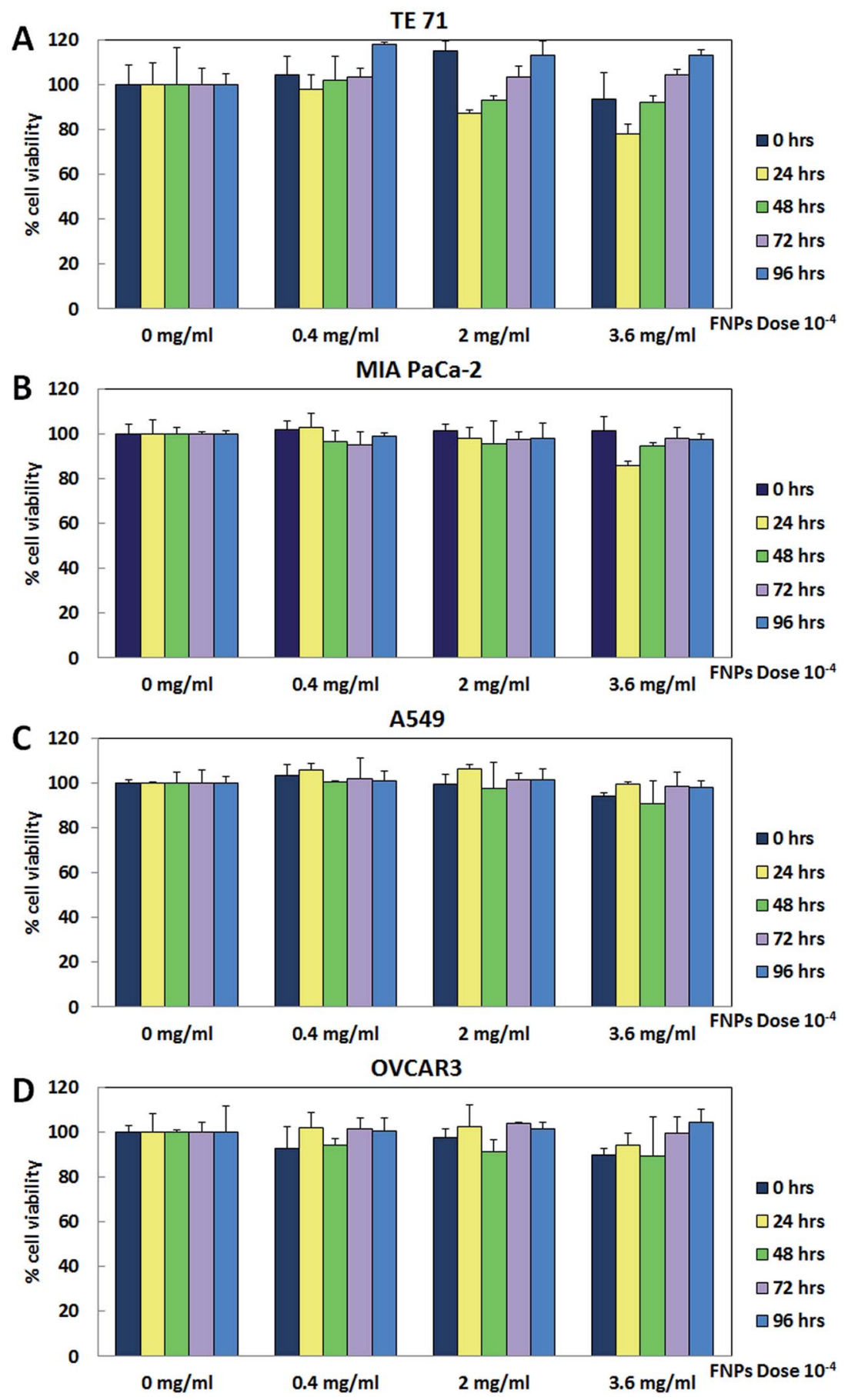

Fig. 5 Intrinsic cytotoxicity of FNPs quantified by MTS viability assay for (A) TE 71, (B) MIA PaCa-2, (C) A549, and (D) OVCAR3 cell lines incubated with different doses of FNPs and kept in dark. MTS assays were run up to 96 hours after incubation with FNPs.

molecular oxygen to form the highly reactive singlet oxygen (type I photooxidation)..$^{5,7,10,11}$ In other instances, charge transfer can occur to molecular oxygen to form superoxide or to other substrates such as solvent molecules and biomolecules (lipids, DNA, nucleic acids etc.) to form radicals (type II photooxidation). ${ }^{5,7,10,11}$ The reactive superoxide radicals then form hydrogen peroxide by grabbing an electron which in presence of $\mathrm{Fe}(\mathrm{II})$ can form hydroxyl radicals. ${ }^{63-66}$ The hydroxyl radicals lead to lipid peroxidation and cause damage to cell organelles. ${ }^{64}$ Thus it was hypothesized that MEH-PPV, upon photoexcitation would effectively photosensitize the formation of singlet oxygen or superoxide radicals, and that FNPs would not require a photosensitizing dopant.

The generation of ROS in cells treated with FNPs and irradiated with light, i.e. PDT experiment, was detected by CellRox Green reagent (CGR). CGR has weak to no fluorescence in its 
reduced form. When CGR is oxidized by ROS in the cells, it displays bright green fluorescence. Fig. 6D shows epiluminescence images of OVCAR3, A549, MIA PaCa-2 and TE 71 cell lines administered with $2 \times 10^{-4} \mathrm{mg} \mathrm{ml}^{-1}$ FNPs and photoirradiated with $180 \mathrm{~J} \mathrm{~cm}^{-2}$ of light. After PDT the cells were incubated for 2 hours before staining with CGR. The CGR fluoresces bright green only in the OVCAR3 cell line as only OVCAR3 has uptaken FNPs and so ROS are generated only in this cell line turning the CGR color bright green. Even though the A549 cell line has shown small amounts of FNP uptake (Fig. 3), that amount is not sufficient to produce ROS detectable by CGR. MIA PaCa- 2 and TE 71 cell lines show no emission from CGR as there was no uptake of FNPs, hence no ROS formation.

The fact that ROS formation in the cells is due to PDT and not intrinsic cytotoxicity of FNPs such as previously observed for, for instance, quantum dots, which lead to elevated ROS even in absence of light, ${ }^{67,68}$ was confirmed by performing three negative controls stained with CGR shown in Fig. 6A-C (A) in absence of PDT (no FNPs, no light), (B) in absence of FNPs with $180 \mathrm{~J} \mathrm{~cm}^{-2}$ light dose, and (C) in absence of light with $2 \times 10^{-4}$ $\mathrm{mg} \mathrm{ml}^{-1}$ FNPs dose). As no emission from CGR was observed in Fig. 6B, it can be concluded that there is no ROS formation in absence of FNPs and that the light dosage alone did not form ROS. Thus, there is no phototoxicity up to the $180 \mathrm{~J} \mathrm{~cm}^{-2}$ light dose. The phase contrast images show that the light has no adverse effect on the morphology of the cells. Fig. 6C shows no CGR emission in any of the four cell lines when the cells are administered with FNPs but are not irradiated with light. This confirms that ROS are not formed when the FNPs are not photoactivated. This is also a confirmation of the negative results of the intrinsic cytotoxicity by MTS assay when cells are kept in dark (Fig. 5). These negative controls show that FNPs uptaken by the cells and exposed to light are the source of ROS formation, hence the oxidative stress in the cells. Fig. $6 \mathrm{E}$ is the positive control for formation of ROS in which all the cell lines are treated with $100 \mu \mathrm{M} \mathrm{H}_{2} \mathrm{O}_{2}$.

\section{Quantitative measurements on cell viability after PDT}

The quantitative effect of PDT on the studied cell lines was measured by MTS cell viability assays. Fig. 7 shows the \% cell viability after PDT. For each cell line the viabilities at the three different FNPs doses $\left(0.4 \times 10^{-4} \mathrm{mg} \mathrm{ml}^{-1}, 2 \times 10^{-4} \mathrm{mg} \mathrm{ml}^{-1}\right.$ and $3.6 \times 10^{-4} \mathrm{mg} \mathrm{ml}^{-1}$ ) is compared with the viability at the control FNPs dose $\left(0 \mathrm{mg} \mathrm{ml^{-1 }}\right)$. MTS assay was performed immediately after PDT (Fig. S5 $\dagger$ ) and 4 hours post-PDT to evaluate further progression after PDT (Fig. 7). It was shown previously that with the use of composite MEH-PPV/PCBM NPS for PDT, 4 hours is a sufficient time to cause nearly $100 \%$ cell mortality. ${ }^{69}$ The measurements revealed that the viability of TE 71, MIA PaCa-2 and A549 cell lines is almost 100\%. In OVCAR3 cell line, the viability decreases with increase in FNPs dose. It is a well-accepted fact that $90 \%$ of ovarian cancer cells overexpress FRs, ${ }^{17,46-49}$ and the expression of FRs on ovarian carcinoma is very homogenous. ${ }^{50}$ Therefore, the OVCAR3 cell line is considered as the FR+ cancer cell line. Thus, there is preferential uptake of the folic acid conjugated nanoparticles by ovarian cancer cells through receptor mediated uptake. ${ }^{70,71}$ In A549 the expression of FRs is marginal although not completely absent. ${ }^{17,18,72}$ In MIA PaCa-2 there is no FR overexpression. ${ }^{\mathbf{6 0 , 6 1}}$ and so this is considered as the FR- cancer cell line. The TE 71 cell line has little to no FR expression and is the normal control cell line. Due to high overexpression of FR in OVCAR3 the uptake of FNPs is abundant through receptor mediated endocytosis. As the FNPs dose increases the amount of FNPs uptaken
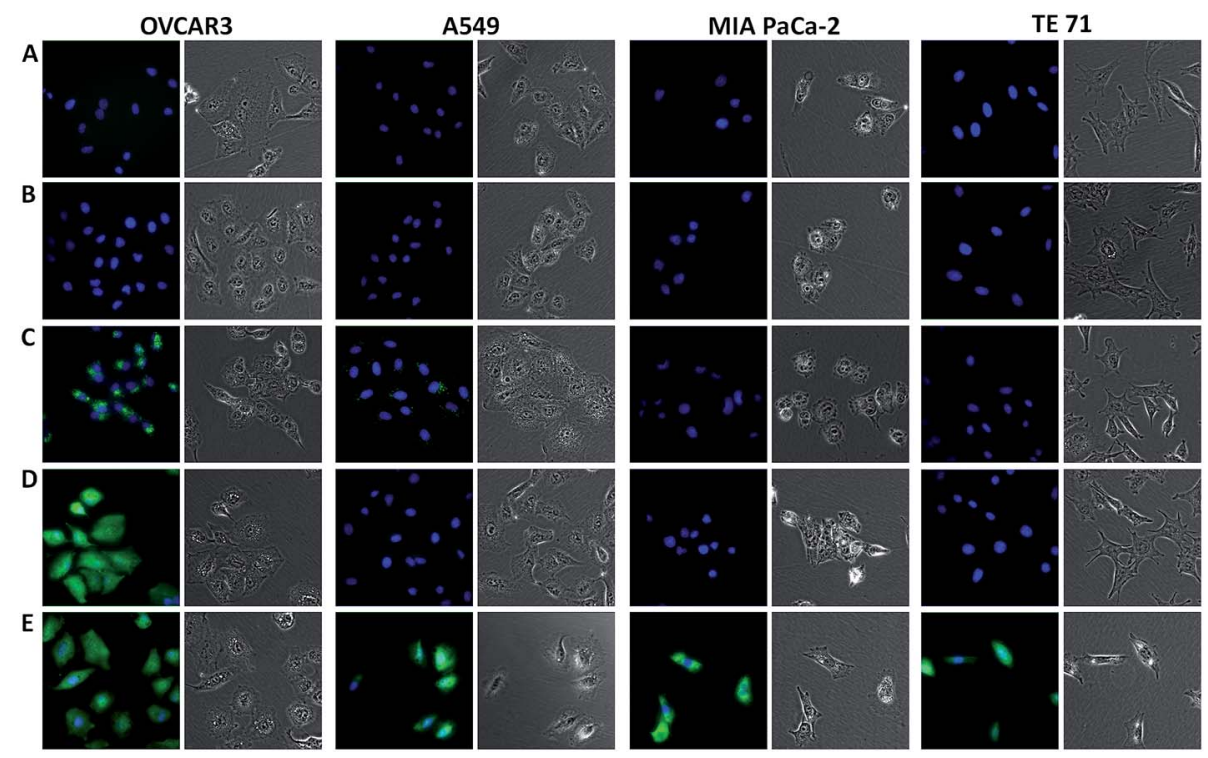

Fig. 6 Detection of ROS generated after PDT in TE 71, MIA PaCa-2, A549 and OVCAR3 cell lines. (A) negative control (no FNPs, no light), (B) negative control with $180 \mathrm{~J} \mathrm{~cm}^{-2}$ (no FNPs) indicates no photocytotoxicity is observed, (C) negative control with $2 \times 10^{-4} \mathrm{mg} \mathrm{ml}^{-1} \mathrm{FNPs}$ (no light) indicates no intrinsic cytotoxicity, (D) 2 hours post-PDT, (E) positive control with $100 \mu \mathrm{M} \mathrm{H}_{2} \mathrm{O}_{2}$. The green color in (C) is fluorescence of FNPs. The green color in $\mathrm{E}$ is CellRox green dye oxidized due to the presence of ROS. 


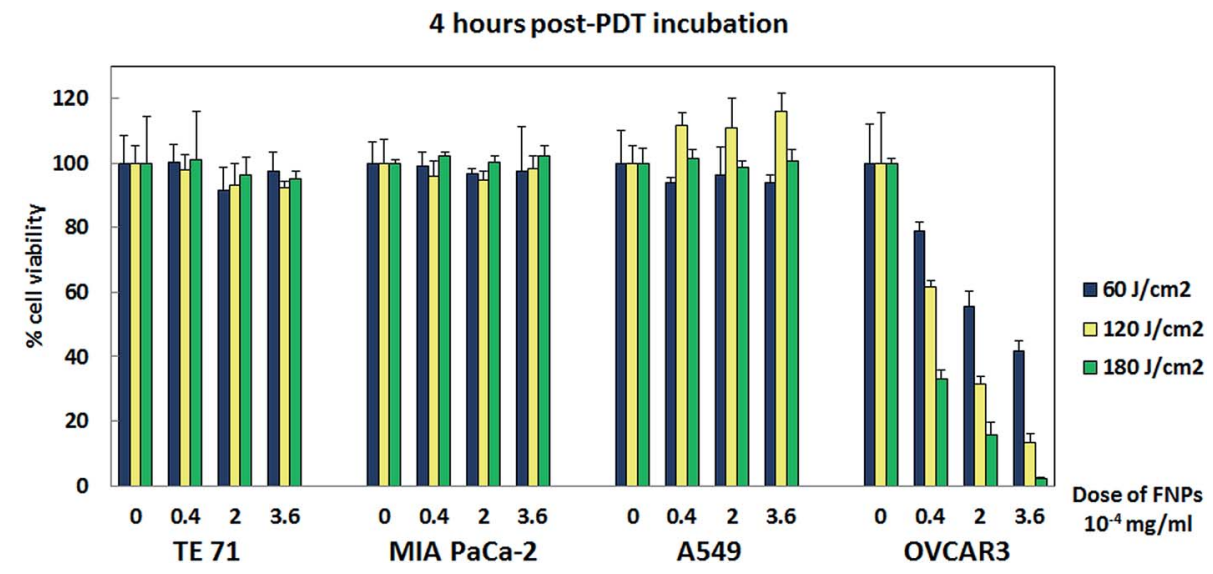

Fig. 7 MTS cell viability assay to quantify results from PDT for TE 71, MIA PaCa-2, A549 and OVCAR3 cell lines incubated with different doses of FNPs and irradiated with 3 doses of light. The post-PDT incubation time is 4 hours (see Fig. S5† for 0 hours post-PDT incubation time).

by the OVCAR3 cells increases. At the same time the population of cells that uptake FNPs also increases. This increase in amount of FNPs in many cells leads to formation of more ROS in the large number of cells, which reflects in low percent cell viability. In MIA PaCa-2 due to absence of FR expression, no FNPs uptake occurred and so the viability is almost $100 \%$. For A549 there is small uptake of FNPs due to less FR expression (Fig. 3). The amount of FNPs is not sufficient to result in oxidative stress in the A549 cell line. Thus the viability is approximately $100 \%$. The TE 71 which also has little to no overexpression of FRs on the plasma membrane, there is no uptake of FNPs and cell viability is $100 \%$. Also, as the light dose increases $\left(60 \mathrm{~J} \mathrm{~cm}^{-2}, 120 \mathrm{~J} \mathrm{~cm}^{-2}\right.$ and $180 \mathrm{~J} \mathrm{~cm}^{-2}$ ) the cell viability in OVCAR3 cell line decreases implying a larger amount of ROS formation with higher dose of light.

\section{Quantification of PDT results by flow cytometry}

The pathway through which cell death occurs depends on (1) the photosensitizer and cell line combination, (2) the PDT dosage and (3) the subcellular or subtissular localization of the photosensitizer. Luo et al. showed that when photosensitizer chloroaluminum phthalocyanine dispersed throughout the cytoplasm $90 \%$ of murine leukemia P388 cells underwent apoptosis at low light dosage. ${ }^{73}$ At higher dosage of light more membrane photodamage was observed, which was found to inhibit apoptosis. Jori et al. have shown that PDT with zinc phthalocyanine (ZnPc) photosensitizer in MS-2 fibrosarcoma induced random necrotic and apoptotic cell deaths due to different subcellular and/or subtissular distribution of the photosensitizer. ${ }^{74}$ Here, PI and annexin V FITC staining was completed after PDT with 4 hours of post-PDT incubation to evaluate cell death efficiency and pathways by flow cytometry. Flow cytometry data are shown in Fig. 8. The annexin V FITC fluorescence intensity is plotted on the $x$-axis and the PI fluorescence is plotted on the $y$-axis. The red dots correspond with the control samples while the black dots correspond with samples treated with PDT. The lower left quadrant in the dot plots show cells which are viable. The lower right quadrants indicate cells which are positive for annexin V-FITC, but negative for PI indicating apoptotic cells. The upper left quadrants show the fraction of the cell population exhibiting only PI fluorescence, indicating necrotic cells. The cell population in the upper right quadrant is dual stained by annexin V-FITC and PI. Looking at the flow cytometry data for PDT (black dots) in OVCAR3 cell line (Fig. 8D), almost $75 \%$ of the cells are dual stained, 14\% cells are stained by PI only (necrotic) and $6 \%$ cells are stained by annexin V-FITC (apoptotic).

For the dual stained cells (Fig. S6†), it is difficult to distinguish the cell death pathway. Arguments can be made that the cells have undergone either apoptotic death, or necrotic death, or a random combination of necrotic and apoptotic death. The first possibility is that the cells have gone through apoptotic death, which would give a positive signal for fluorescence of annexin V-FITC. Since these are in vitro experiments there is no mechanism of phagocytosis to destroy the apoptotic cells, which allows the cells go into the apoptotic necrosis stage. At this stage the cells become permeable to PI stain and as a result become dual stained. The second possibility is that the cells have gone through necrosis, which would give a positive signal for fluorescence of PI. After cell death non-specific binding of annexin V-FITC to the cells becomes possible so that the cells get stained with annexin V-FITC as well and show up in the dual stained quadrant of the flow cytometry data. The third possibility is that different cells might have undergone both necrotic or apoptotic deaths randomly to form a mixed population of apoptotic and necrotic cells.

For clarity the flow cytometry data was also plotted as bar graphs as shown in Fig. 8E-H. It can be seen from Fig. 8E that the percentage of live cells in all the cell lines but OVCAR3 is almost same as the control (no PDT) and that there is no death because of PDT as these cell lines have not uptaken FNPs. On the other hand, in OVCAR3 cell line the percent of live cells is only 5 . These data are very consistent with the data obtained by MTS cell viability assay (Fig. 7). Thus flow cytometry and MTS cell viability both confirm the effect of PDT on the cell lines studied here. The MIA PaCa-2 cell line was found to be very sensitive to handle during culture and was the reason of 

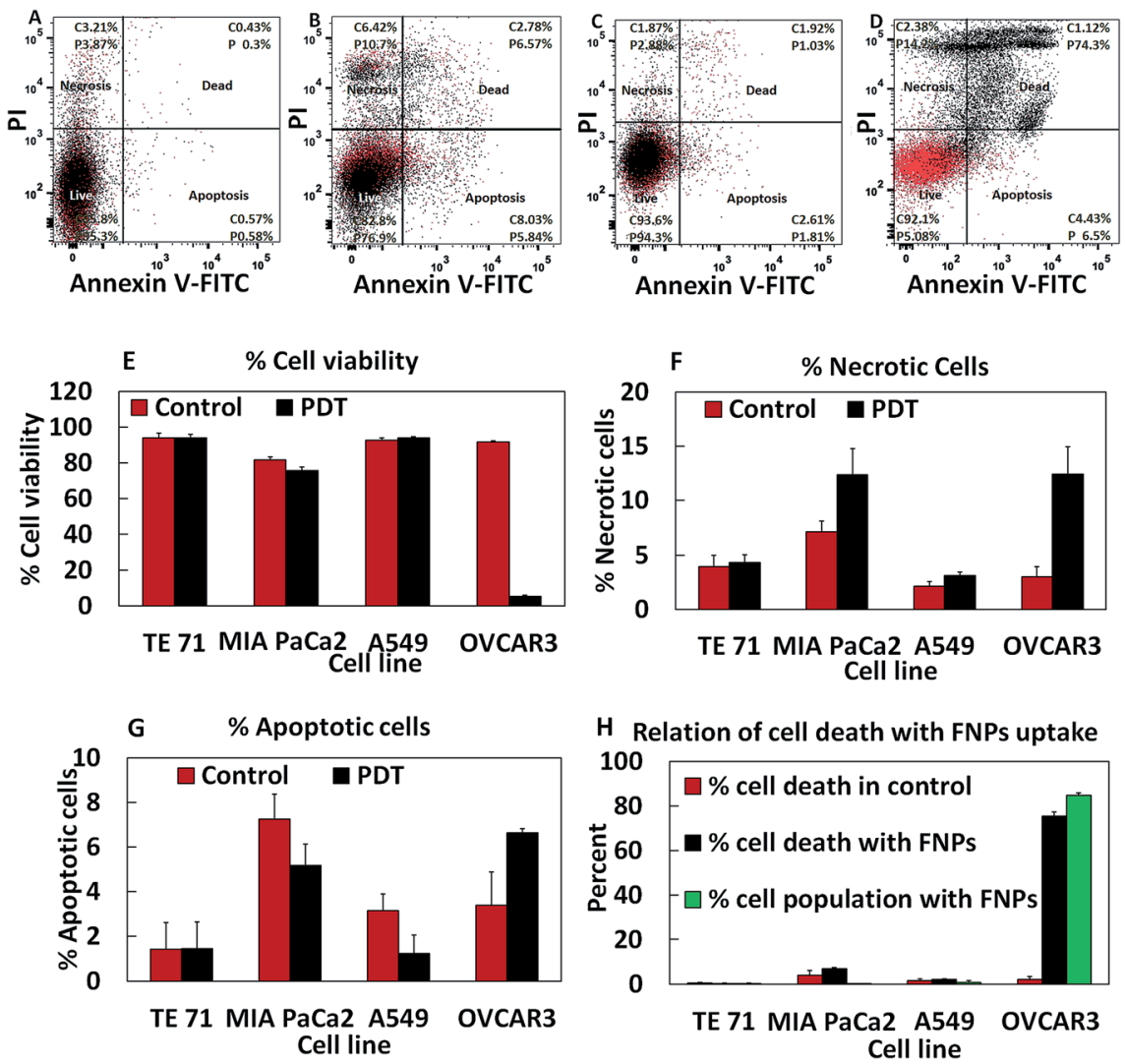

Fig. 8 Flow cytometry to quantify cell mortality after PDT. Dot plots are for (A) TE 71, (B) MIA PaCa-2, (C) A549 and (D) OVCAR3 cell lines stained with FITC annexin V and PI. The red dots are the cells from control and the black dots are the cells from PDT experiment. The four quadrants in each plot are labeled for live (lower left), apoptotic (lower right), necrotic (upper left) and dual stained cells (upper right) along with percentages in each quadrant. The data are plotted as bar graphs for clarity in E-H. (E) Percent cell viability in each cell line after PDT, (F) percent of necrotic cells in each cell line after PDT, (G) percent of apoptotic cells after PDT, and (H) relation between \% cell population with FNPs and \% cell death after PDT in each cell line. In each bar graph the percentages are compared with the corresponding control experiments.

showing approximately $85 \%$ live cells in both control and PDT experiment. The OVCAR3 cell line has $14 \%$ necrotic cells (Fig. 8F) while only 6.5\% apoptotic cells (Fig. 8G). The percent of dead cells is shown in Fig. 8H. OVCAR3 has almost $75 \%$ of dead cells. The \% cell death in OVCAR3 cell line can be directly related to the \% cell population which has uptaken FNPs (green bars in Fig. $8 \mathrm{H}$ ). The $\%$ cell population which has uptaken FNPs is 84 . When PDT is performed on these cells, the \% cell death is 75 and can be directly related to the formation of ROS which leads to death.

\section{Conclusions}

Blended MEH-PPV/PS-PEG-COOH nanoparticles conjugated with folic acid (FNPs) were studied in vitro for use in PDT as next generation photosensitizers with targeted delivery. The FNPs were found to be selectively targeting cancer cell lines that overexpress folate receptors (FR) and exhibited no dark toxicity. In vitro PDT experiments show near complete cell mortality for the cancer cell line that abundantly overexpresses the targeted receptor (OVCAR3) while no cell mortality is observed for nontargeted (TE 71 normal control and MIA PaCa-2) or marginally receptor overexpressing cell lines (A549). The high extinction coefficient, effective ROS generation, high degree of uptake selectivity, absence of dark toxicity, inclusion of PEG which may enhance circulation times for in vivo applications, and observation of cell mortality only for abundantly receptor overexpressing target cell line indicate the promising nature of this photosensitizer system for targeted PDT.

\section{Acknowledgements}

The authors gratefully acknowledge the National Science Foundation (NSF) for financial support of this work through a CAREER award (CBET-0746210, MD, AJG), through award CBET-1159500 (MD, AJG, SK), and through REU site EEC1156747 (MK, HS, AJG).

\section{References}

1 Statistics: Major Milestones Against Cancer, http:// www.cancerprogress.net/timeline-statistics/major-milestonesagainst-cancer.

2 Cancer Stat Fact Sheets, http://seer.cancer.gov/statfacts/.

3 S. B. Brown, E. A. Brown and I. Walker, Lancet Oncol., 2004, 5(8), 497-508. 
4 C. Hopper, Lancet Oncol., 2000, 1(4), 212-219.

5 T. J. Dougherty, C. J. Gomer, B. W. Henderson, G. Jori, D. Kessel, M. Korbelik, J. Moan and Q. Peng, J. Natl. Cancer Inst., 1998, 90(12), 889-905.

6 D. Vyas, P. Castro, Y. Saadeh and A. Vyas, J. Biomed. Nanotechnol., 2014, 10(11), 3204-3218.

7 D. E. J. G. J. Dolmans, D. Fukumura and R. K. Jain, Nat. Rev. Cancer, 2003, 3(5), 380-387.

8 M. B. Vrouenraets, G. W. M. Visser, G. B. Snow and G. van Dongen, Anticancer Res., 2003, 23(1B), 505-522.

9 B. C. Wilson, Can. J. Gastroenterol. Hepatol., 2002, 16(6), 393396.

10 B. W. Henderson and T. J. Dougherty, Photochem. Photobiol., 1992, 55(1), 145-157.

11 N. L. Oleinick, R. L. Morris and T. Belichenko, Photochem. Photobiol. Sci., 2002, 1(1), 1-21.

12 K. Berg, P. K. Selbo, A. Weyergang, A. Dietze, L. Prasmickaite, A. Bonsted, B. Ø. Engesaeter, E. Angell-Petersen, T. Warloe, N. Frandsen and A. HØGset, J. Microsc., 2005, 218(2), 133147.

13 E. Buytaert, M. Dewaele and P. Agostinis, Biochim. Biophys. Acta, Rev. Cancer, 2007, 1776(1), 86-107.

14 J.-M. Houle and H. A. Strong, Retina, 2002, 22(6), 691-697.

15 S.-I. Moriwaki, J. Misawa, Y. Yoshinari, I. Yamada, M. Takigawa and Y. Tokura, Photodermatol., Photoimmunol. Photomed., 2001, 17(5), 241-243.

16 G. A. M. S. van Dongen, G. W. M. Visser and M. B. Vrouenraets, Adv. Drug Delivery Rev., 2004, 56(1), 31-52.

17 J. F. Ross, P. K. Chaudhuri and M. Ratnam, Cancer, 1994, 73(9), 2432-2443.

18 S. D. Weitman, R. H. Lark, L. R. Coney, D. W. Fort, V. Frasca, V. R. Zurawski and B. A. Kamen, Cancer Res., 1992, 52(12), 3396-3401.

19 F. X. Real, W. J. Rettig, P. G. Chesa, M. R. Melamed, L. J. Old and J. Mendelsohn, Cancer Res., 1986, 46(9), 4726-4731.

20 N. Ahmed, V. S. Salsman, E. Yvon, C. U. Louis, L. Perlaky, W. S. Wels, M. K. Dishop, E. E. Kleinerman, M. Pule, C. M. Rooney, H. E. Heslop and S. Gottschalk, Mol. Ther., 2009, 17(10), 1779-1787.

21 K. Subik, J.-F. Lee, L. Baxter, T. Strzepek, D. Costello, P. Crowley, L. Xing, M.-C. Hung, T. Bonfiglio, D. G. Hicks and P. Tang, Breast Cancer, 2010, 4, 35-41.

22 A. Narsireddy, K. Vijayashree, J. Irudayaraj, S. V. Manorama and N. M. Rao, Int. J. Pharm., 2014, 471(1-2), 421-429.

23 Y. Mir, S. A. Elrington and T. Hasan, Nanomedicine, 2013, 9(7), 1114-1122.

24 W.-J. Syu, H.-P. Yu, C.-Y. Hsu, Y. C. Rajan, Y.-H. Hsu, Y.-C. Chang, W.-Y. Hsieh, C.-H. Wang and P.-S. Lai, Small, 2012, 8(13), 2060-2069.

25 V. Morosini, T. Bastogne, C. Frochot, R. Schneider, A. Francois, F. Guillemin and M. Barberi-Heyob, Photochem. Photobiol. Sci., 2011, 10(5), 842-851.

26 B. S. Wang, J. Wang and J.-Y. Chen, J. Mater. Chem. B, 2014, 2(11), 1594-1602.

27 P. Huang, C. Xu, J. Lin, C. Wang, X. Wang, C. Zhang, X. Zhou, S. Guo and D. Cui, Theranostics, 2011, 1, 240-250.
28 P. Agostinis, K. Berg, K. A. Cengel, T. H. Foster, A. W. Girotti, S. O. Gollnick, S. M. Hahn, M. R. Hamblin, A. Juzeniene, D. Kessel, M. Korbelik, J. Moan, P. Mroz, D. Nowis, J. Piette, B. C. Wilson and J. Golab, Ca-Cancer J. Clin., 2011, 61(4), 250-281.

29 Z. Huang, Technol. Cancer Res. Treat., 2005, 4(3), 283-293.

30 J. L. Grimland, C. Wu, R. R. Ramoutar, J. L. Brumaghim and J. McNeill, Nanoscale, 2011, 3(4), 1451-1455.

31 X. Shen, L. Li, H. Wu, S. Q. Yao and Q.-H. Xu, Nanoscale, 2011, 3(12), 5140-5146.

32 Y. Zhang, L. Pang, C. Ma, Q. Tu, R. Zhang, E. Saeed, A. E. Mahmoud and J. Wang, Anal. Chem., 2014, 86(6), 3092-3099.

33 C. Wu, T. Schneider, M. Zeigler, J. Yu, P. G. Schiro, D. R. Burnham, J. D. McNeill and D. T. Chiu, J. Am. Chem. Soc., 2010, 132(43), 15410-15417.

34 S. L. Sewell and T. D. Giorgio, Mater. Sci. Eng., C, 2009, 29(4), 1428-1432.

35 Z. Zhang, J. Jia, Y. Lai, Y. Ma, J. Weng and L. Sun, Bioorg. Med. Chem., 2010, 18(15), 5528-5534.

36 C. Chen, J. Ke, X. E. Zhou, W. Yi, J. S. Brunzelle, J. Li, E.-L. Yong, H. E. Xu and K. Melcher, Nature, 2013, 500(7463), 486-489.

37 B. J. Schwartz, Annu. Rev. Phys. Chem., 2003, 54(1), 141-172. 38 C. Szymanski, C. Wu, J. Hooper, M. A. Salazar, A. Perdomo, A. Dukes and J. McNeill, J. Phys. Chem. B, 2005, 109(18), 8543-8546.

39 D. Tenery, J. G. Worden, Z. Hu and A. J. Gesquiere, J. Lumin., 2009, 129(5), 423-429.

40 R. Traiphol, P. Sanguansat, T. Srikhirin, T. Kerdcharoen and T. Osotchan, Macromolecules, 2006, 39(3), 1165-1172.

41 S. A. Jenekhe and J. A. Osaheni, Science, 1994, 265, 765-768.

42 T.-H. Chung, S.-H. Wu, M. Yao, C.-W. Lu, Y.-S. Lin, Y. Hung, C.-Y. Mou, Y.-C. Chen and D.-M. Huang, Biomaterials, 2007, 28(19), 2959-2966.

43 S. E. A. Gratton, P. A. Ropp, P. D. Pohlhaus, J. C. Luft, V. J. Madden, M. E. Napier and J. M. DeSimone, Proc. Natl. Acad. Sci. U. S. A., 2008, 105(33), 11613-11618.

44 P. S. Xu, E. A. Van Kirk, Y. H. Zhan, W. J. Murdoch, M. Radosz and Y. Q. Shen, Angew. Chem., Int. Ed., 2007, 46(26), 4999-5002.

45 Y. Zhang, M. Yang, N. G. Portney, D. X. Cui, G. Budak, E. Ozbay, M. Ozkan and C. S. Ozkan, Biomed. Microdevices, 2008, 10(2), 321-328.

46 A. C. Antony, Annu. Rev. Nutr., 1996, 16(1), 501-521.

47 I. G. Campbell, T. A. Jones, W. D. Foulkes and J. Trowsdale, Cancer Res., 1991, 51(19), 5329-5338.

48 J. Sudimack and R. J. Lee, Adv. Drug Delivery Rev., 2000, 41(2), 147-162.

49 W. Scarano, H. T. T. Duong, H. Lu, P. L. De Souza and M. H. Stenzel, Biomacromolecules, 2013, 14(4), 962-975.

50 P. Garinchesa, I. Campbell, P. E. Saigo, J. L. Lewis, L. J. Old and W. J. Rettig, Am. J. Pathol., 1993, 142(2), 557-567.

51 D. J. Bharali, D. W. Lucey, H. Jayakumar, H. E. Pudavar and P. N. Prasad, J. Am. Chem. Soc., 2005, 127(32), 11364-11371.

52 H. Choi, S. R. Choi, R. Zhou, H. F. Kung and I. W. Chen, Acad. Radiol., 2004, 11(9), 996-1004. 
53 S. Hwa Kim, J. Hoon Jeong, C. O. Joe and T. Gwan Park, J. Controlled Release, 2005, 103(3), 625-634.

54 M. Koyakutty, J. Seby, T. Deepa, S. Sonali, M. Deepthy and N. Shantikumar, Nanotechnology, 2009, 20(6), 065102.

55 D. Lee, R. Lockey and S. Mohapatra, J. Nanosci. Nanotechnol., 2006, 6(9-1), 2860-2866.

56 L. Li, Q. Yang, Z. Zhou, J. Zhong and Y. Huang, Biomaterials, 2014, 35(19), 5171-5187.

57 S. Setua, D. Menon, A. Asok, S. Nair and M. Koyakutty, Biomaterials, 2010, 31(4), 714-729.

58 F. Tavassolian, G. Kamalinia, H. Rouhani, M. Amini, S. N. Ostad, M. R. Khoshayand, F. Atyabi, M. R. Tehrani and R. Dinarvand, Int. J. Pharm., 2014, 467, 123-138.

59 H. S. Yoo and T. G. Park, J. Controlled Release, 2004, 100(2), 247-256.

60 C. Rudroff, H. Schafberg, G. t. Nowak, R. Weinel, J. Scheele and R. Kaufmann, Pancreas, 1998, 16(2), 189-194.

61 L. Yang, H. Mao, Y. A. Wang, Z. Cao, X. Peng, X. Wang, H. Duan, C. Ni, Q. Yuan, G. Adams, M. Q. Smith, W. C. Wood, X. Gao and S. Nie, Small, 2009, 5(2), 235-243.

62 H. D. Burrows, J. Seixas de Melo, C. Serpa, L. G. Arnaut, M. d. G. Miguel, A. P. Monkman, I. Hamblett and S. Navaratnam, Chem. Phys., 2002, 285(1), 3-11.

63 M. W. Fariss, C. B. Chan, M. Patel, B. Van Houten and S. Orrenius, Mol. Interventions, 2005, 5(2), 94-111.
64 B. Halliwell and S. Chirico, Am. J. Clin. Nutr., 1993, 57(5), S715-S725.

65 B. Halliwell and J. M. C. Gutteridge, Biochem. J., 1984, 219(1), 1-14.

66 M. Valko, D. Leibfritz, J. Moncol, M. T. D. Cronin, M. Mazur and J. Telser, Int. J. Biochem. Cell Biol., 2007, 39(1), 44-84.

67 M. Green and E. Howman, Chem. Commun., 2005, 1, 121123.

68 J. Lovric, S. J. Cho, F. o. M. Winnik and D. Maysinger, Chem. Biol., 2005, 12(11), 1227-1234.

69 M. Doshi, K. Treglown, A. Copik and A. Gesquiere, BioNanoScience, 2014, 4(1), 15-26.

70 N. V. Nukolova, H. S. Oberoi, S. M. Cohen, A. V. Kabanov and T. K. Bronich, Biomaterials, 2011, 32(23), 5417-5426.

71 J. Yang, E.-J. Cho, S. Seo, J.-W. Lee, H.-G. Yoon, J.-S. Suh, Y.-M. Huh and S. Haam, J. Biomed. Mater. Res., Part A, 2008, 84(1), 273-280.

72 H. Yuan, J. Miao, Y.-Z. Du, J. You, F.-Q. Hu and S. Zeng, Int. J. Pharm., 2008, 348(1-2), 137-145.

73 Y. Luo and D. Kessel, Photochem. Photobiol., 1997, 66(4), 479483.

74 G. Jori and C. Fabris, J. Photochem. Photobiol., B, 1998, 43(3), 181-185. 